\title{
VOCATIONAL TRAINING COSTS AND ECONOMIC BENEFITS: EXPLORING THE INTERACTIONS
}

\author{
Natalia SAMOLIUK (D)1, Yuriy BILAN (iD)2,3*, Halyna MISHCHUK (D)4 \\ ${ }^{1}$ Labour Resources and Entrepreneurship Department, \\ National University of Water and Environmental Engineering, Rivne, Ukraine \\ ${ }^{2}$ Alexander Dubcek University of Trencin, Trencin, Slovakia \\ ${ }^{3}$ Sumy State University, Sumy, Ukraine \\ ${ }^{4}$ Labour Resources and Entrepreneurship Department, \\ National University of Water and Environmental Engineering, Rivne, Ukraine
}

Received 09 May 2021; accepted 04 July 2021

\begin{abstract}
The aim of the article is to study the relationship between vocational training costs and economic benefits at different levels of economic relations. In the structure of labour costs in the EU, there was the highest share of vocational training costs in Ireland (2.79\%), Great Britain (2.53\%), France (1.51\%), which is reflected in the economic success of these countries. A comparison with Ukraine, which has European integration intentions, confirms that the underestimated role of investing in lifelong learning has relevant links to economic performance. This study at the enterprise level (based on the survey of 356 employees) found that higher costs of vocational training are a sign of profitable enterprises. At the same time, employees' interest in short-term training programs is higher, which they obviously assess from the standpoint of higher personal economic benefits in the short term. At the same time, the analysis performed by means of the Fechner correlation coefficient confirms the existence of a positive impact of vocational training costs on changes in the main macroeconomic benefits indicator - GDP per capita. This allows drawing conclusions about the need to develop professional training programs for staff as one of the drivers of macroeconomic development.
\end{abstract}

Keywords: economic benefits, economic growth, correlation, labour costs, GDP, vocational training costs.

JEL Classification: J24, J32, D83, E24.

\section{Introduction}

Today, the expenses for professional training of employees is one of the determinants of human development and at the same time is one of the key factors of macroeconomic efficiency. The awareness of this is reflected both in individual decisions on vocational training and in

\footnotetext{
${ }^{\star}$ Corresponding author. E-mail: y.bilan@prz.edu.pl
} 
best business practices. At the macroeconomic level, this area of investment in human capital is a recognized factor in progress in measuring human development; the indicator "Labor share of GDP, comprising wages and social protection transfers" is one of the indicators of progress in assessing the National income and composition of resources (United Nations Development Programme, 2019). At the same time, in the countries that are consistently among the leaders in both human and economic development, in particular, in Australia and the United Kingdom, there have been special centers established: National Center for Vocational Education and Training (NCVER), Australia; Center for Vocational Education Research (CVER), UK. At the same time, one of the agreements developed with the participation of the Australian Government's Productivity Commission to develop workers' skills declared not only the promotion of personal benefits in the form of "increased rates of workforce participation", but also enables all working age Australians to participate effectively in the labour market and contribute to Australia's economic future" (Australian Government, 2020, p. 4).

Vocational training has a stable positive effect for employees - the share of those who successfully found employment after graduation between 2008 and 2019 was in the range between $91.5 \%$ and $92.9 \%$, in contrast to those who never completed training (non-completers) - from $74.1 \%$ to $76.0 \%$, respectively (National Center for Vocational Education and Training [NCVER], 2020, p. 13). Of course, vocational training sometimes has negative economic consequences for business owners - after completing training, employees are more likely to be ready to change employer after apprenticeship or traineeship with "employment related reasons", realizing that they can get better job and higher earnings (NCVER, 2020, p. 24). Nevertheless, the increase of the quality of human capital has far more advantages than disadvantages, especially given the overall implications for the labour market. Therefore, attention to studies of the effect of vocational training costs (VTC) remains high. Its impact is studied in various manifestations: methodologically, taking into account changes in the labour market under the influence of innovation, including the fourth industrial revolution (Avis, 2018); based on the analysis of statistics on the coverage of education and its economic consequences for the economy of countries (Bhorat et al., 2016; Chung \& Tseng, 2019); and assessments of the links between learning and its outcomes found in specially conducted studies (Choi et al., 2019; Martins, 2020; Mason, 2020; Shah, 2017).

According to the opinion of other researchers it is not enough to have some consolidated, universal information on the dynamics, directions of VTC and it is difficult to create it, because there is a need to take into account the specifics of training and efficiency of such funds (Muehlemann, 2019, p. 198). The source of such information is formed by relevant surveys of entrepreneurs and employees. Such research is useful for finding effective ways to manage human capital at the microlevel in the short term. However, using this information to understand macroeconomic relationships is virtually impossible.

The aim of this work is to study the economic benefits of vocational training costs through a two-level analysis - at the country level and based on the results of a survey of enterprise personnel. To do this, the existing methodological principles of research based on traditional methods of statistical analysis and sociological research are supplemented. The novelty of the authors' approach is the addition of such approaches to assess the impact of VTC on macroeconomic results using one of the atypical tools of correlation analysis - Fechner correlation 
coefficient. It is more in line with the purpose of the study, as it allows taking into account the existing average standards for staff development in the study group of countries. This approach better illustrates the homogeneity of the population and the direction of changes in it in the chosen direction of research in contrast to traditional methods of studying the correlation using individual values of indicators.

The study is organized as follows. The first section is devoted to a literature review and research hypotheses, proceeded by describing the utilized methods and data sources in the second section. The third section explains the findings obtained from applying the designed framework to the study, and, ultimately, the last section presents the conclusion.

\section{Literature review}

Today, the use of Cost-Benefit Analysis dominates in assessing the impact of the VTC on the economic impact of investment decisions. Such calculations have become traditional for various fields. The feasibility of additional training courses, such as summer courses, has been proven in terms of financial benefits for the entire education system as a correlation between costs and benefits (Reed et al., 2018; Suharno et al., 2019). The benefits are tangible not only for society as a whole, but even more for individuals and firms in the case of employees training organized by their employers. This direction of benefits practices is especially important for business in immature markets with deficit of highly skilled workers (Bilan et al., 2020a).

Workers have a corresponding effect in the form of stable employment and high wages (Görlitz \& Tamm, 2016; Kumar et al., 2019; Saksiriruthai, 2018; Starr, 2019; Yusoff et al., 2018). These consequences have positive impact on overall quality of life, being an important factor of social support from different sources (Wang et al., 2021). There is also feedback: highly paid employees have more training opportunities and, consequently, higher job satisfaction (Krumbiegel et al., 2018). Ultimately, such consequences are beneficial not only for employees, but also for business owners, who are actively developing staff training programs in various forms today.

The greatest economic benefits are assessed at the enterprise level, where the benefits of professional training of employees are confirmed by researchers in the form of significant and measurable economic consequences. For example, in Portugal, "firm-provided additional training led to increased sales, value added, employment, productivity, and exports. These effects tend to be of at least $5 \%$ and, in some cases, $10 \%$ or more" (Martins, 2020).

In addition to measuring the effect of indirect methods (growth of financial and economic indicators after training), as a benefit from the organization of vocational training, it can be determined the difference between training related productivity increase and initial training expenses. It is this difference between a trainee's productivity and the training wage that allows covering firm's training costs (Muehlemann, 2019, p. 202). The impact of learning organized in various forms on productivity growth is not in doubt today, but it only gains new empirical evidence of effectiveness (Al-Ajlouni et al., 2019; Al Karim, 2019; Al Mamun \& Hasan 2017; Bibi, 2018; Boadu et al., 2018; Efobi \& Orkoh, 2018; Falola et al., 2018; Guan \& Frenkel, 2019; Mira \& Odeh, 2019; Mishchuk et al., 2016). These evidences become more obvious in terms of Industry 4.0 and related structural changes within the entrepreneurial 
and educational system (Grenčíková et al., 2021). Considering the steep development of new technologies like cloud service in all business entities, including SMEs, skills of employees should be developed appropriately for new business needs (Dincă et al., 2019).

Therefore, employer-supported education and training accounts for the largest share of adult education and training in all Organization for Economic Cooperation and Development (OECD) countries (Shah, 2017).

In addition to clear motives for staff development to achieve goals (personal and business goals), it is also important to consider that a sign of effective entrepreneurship is a developed social dialogue and a system of collective bargaining in reconciling the mutual interests of employers and employees. Entrepreneurial learning is one of the main objects of such a dialogue (Della Torre, 2019; Bilan et al., 2020b). Given this, as well as the relationship between training costs and economic performance of enterprises, this research is aimed at testing the following hypothesis:

Hypothesis 1 (H1): the costs of vocational education at the enterprise level are related to the profitability of their activities and are more active in enterprises, where the relationship between administration and employees is additionally regulated by a collective agreement.

At the macroeconomic level, the effect of education should be synergistic: the level of education acquired in schools and universities should be enhanced by the impact of vocational training of adult workers. However, assessments of the impact of different forms of education on economic growth, carried out mainly by correlation analysis tools, sometimes lead to unexpected results. In particular, one such study proved that "primary and secondary school enrolment and average years of schooling have a positive and statistically significant effect on economic growth. In contrast, the estimates for both tertiary school enrolment and government expenditure on education are not statistically significant" (Ogundari \& Awokuse, 2018).

In the developed countries, such results can be explained by declining marginal productivity in economic development, which reduces the strength of the correlation with educational factors. In countries with a lower level of economic development, there is a general positive correlation between educational factors and economic performance (Bhorat et al., 2016; Islam et al., 2016). Obviously, in countries with higher levels of economic development, the relevant links may not be significant enough if economic growth and higher education enrolment factors are analysed - in this case, the objectivity of data on the value of education decreases slightly under the influence of intensive student migration to developed countries, which is known to be determined not only by motivation to acquire an education (Mishchuk et al., 2019). At the same time, analysing the impact of education only on adult applicants (18-64 years), the general positive trends are confirmed in the group of developed countries (EU): "More dynamic countries or countries aspiring at fostering their economic growth and well-being are keener on investing into lifelong learning and related issues thus promoting sustainable economic growth and development" (Tvaronavičienè et al., 2018, p. 253).

At the same time, lifelong learning of the adult population can have no other motivation than to improve their own professional level, and on the part of entrepreneurs who finance it - the desire to increase economic performance and business competitiveness. Therefore, if 
the economic consequences of vocational education are analysed today, there is ample evidence of a positive impact on the development of the country or certain activities (Chung \& Tseng, 2019; McGrath \& Powell, 2016; Varma \& Kataria, 2018).

Considering this, the following hypothesis is analysed:

Hypothesis 2 (H2): at the macroeconomic level (in the EU), the link between vocational training costs and GDP per capita is close and positive; it illustrates the homogeneous orientation of educational policy at the business level in different countries of the same group.

\section{Data and method}

Testing research hypotheses requires studying the information of two levels - macroeconomic and business.

To test the $H 1$ hypothesis, the own sociological survey of enterprises is conducted in Rivne, one of the regional centers of Ukraine. The city is located in a cross-border region. The region is characterized by high migration exchange with neighbouring EU countries. Therefore, the awareness of European staff development practices is high enough to assess their impact on personal development opportunities and better employment prospects, which is the main motivation of employees to participate in relevant training programs. Such subjective assessments based on their own comparisons with the practice of neighbouring developed countries are useful in terms of the formation of incentives for their own professional development. In addition, given that the study at the macroeconomic level includes a comparison of staff training costs in Ukraine and the EU, identifying problems of its implementation in Ukraine is one of the steps to improve HR management practices in line with European integration intentions of Ukraine.

The survey was conducted in June - September 2018 in the form of an anonymous survey, when 356 employees from 170 companies were interviewed.

The structure of the respondents was as follows: $64 \%$ - women, $36 \%$ - men; $54 \%$ - employees under the age of 35, 37\% - aged 35-50 years. 51\% belonged to the category of "workers", $42 \%$ - to the category of "professionals", $7 \%$ - to the category of "managers".

The representativeness of the sample of enterprises was checked according to the Cochran formula (Cochran, 1977):

$$
n=\frac{z^{2} p(1-p) N}{z^{2} p(1-p)+N e^{2}},
$$

where $n$ is sample size (356 employees); $N$ is population size (13 570 employees according to the data of the State Statistics Service of Ukraine for the region in which the survey was conducted); $z$ is standard normal variable ( $z=1.96$ at $95 \%$ confidence level); $p$ is proportion or degree of variability $=50 \%$; $e$ is the level of precision.

So, the sample size provides the level of precision at the level of $4.2 \%$.

Further data processing was carried out in a traditional, graph-analytical, way with the identification of features of application of personnel training programs (long- and shortterm) at profitable and unprofitable enterprises, and also depending on existence of the collective agreement. 
H2 hypothesis was tested using EU statistics on indicators:

$-x$ is vocational training costs per employee, euro (Eurostat, 2020b);

- $y$ is GDP per capita, euro (Eurostat, 2020a).

The results of the hypothesis test were performed using statistical data for 2016, because at the time of the study this was the latest available data posted on Eurostat on the structure of labour cost. Therefore, in order to compare the data, indicators on GDP per capita were also taken for 2016.

In this case, the methodology of relationship estimation based on the Fechner correlation coefficient was used, which is described in detail by Kruskal (1958):

$$
\rho F(x, y)=\frac{1}{n} \sum_{i=1}^{n} \operatorname{sgn}\left(x_{i}-\bar{x}\right) \times \operatorname{sgn}\left(y_{i}-\bar{y}\right)=\frac{C-H}{C+H},
$$

where $C+H=n$ and $C=\sum_{i \neq j}\left\{\operatorname{sgn}\left(x_{i}-\bar{x}\right)=\operatorname{sgn}\left(y_{i}-\bar{y}\right)\right\}$ is the number of pairs with the same sign of deviation from the mean value; $H=\sum_{i \neq j}\left\{\operatorname{sgn}\left(x_{i}-\bar{x}\right) \neq \operatorname{sgn}\left(y_{i}-\bar{y}\right)\right\}$ is the number of pairs with the opposite sign of deviation from the mean value.

In contrast to the Pearson correlation coefficient, which is more common in such studies, the Fechner correlation coefficient provides an assessment of the synchrony/asynchrony of deviations from the mean values. Therefore, it better illustrates the homogeneity of the set of countries in the direction of action against average standards, rather than just the links determined by individual values of indicators. This allows taking better into account the existing average standards in educational policy at the business level in different countries of the same group, and especially - the common approaches to building and maintaining personnel development systems (by deviation from the average).

\section{Results}

Vocational training in EU enterprises is an important and widespread area of human capital management. As a result of the analysis of the available data, namely Labour costs surveys 2008, 2012 and 2016 (Eurostat, 2020b), it was found that, in the structure of enterprises' personnel costs, the share of vocational training costs has not changed significantly and is in the range of $0.1-2.8 \%$. Only the positions of countries in terms of expenditures on adult education have changed slightly. In 2008, the share of expenditures on vocational training ranged from $0.16 \%$ in Greece to $2.12 \%$ in France, and in 2016 - from $0.07 \%$ in Belgium to $2.79 \%$ in Ireland (Table 1). When the dynamics of the share of vocational training costs is analysed in terms of individual countries, some instability of this indicator is observed. However, some EU countries show a positive trend in investing in staff training, including Ireland, Finland and Germany.

Comparing such structural indicators of expenditures in the EU and Ukraine, the latter is seen not only to achieve the best or at least average for the EU indicators (from $1.50 \%$ in 2008 to $1.88 \%$ in 2016), but has also a negative dynamic in the structure of VTC. In 2018, the costs of vocational training in Ukraine are many times lower compared to similar costs 


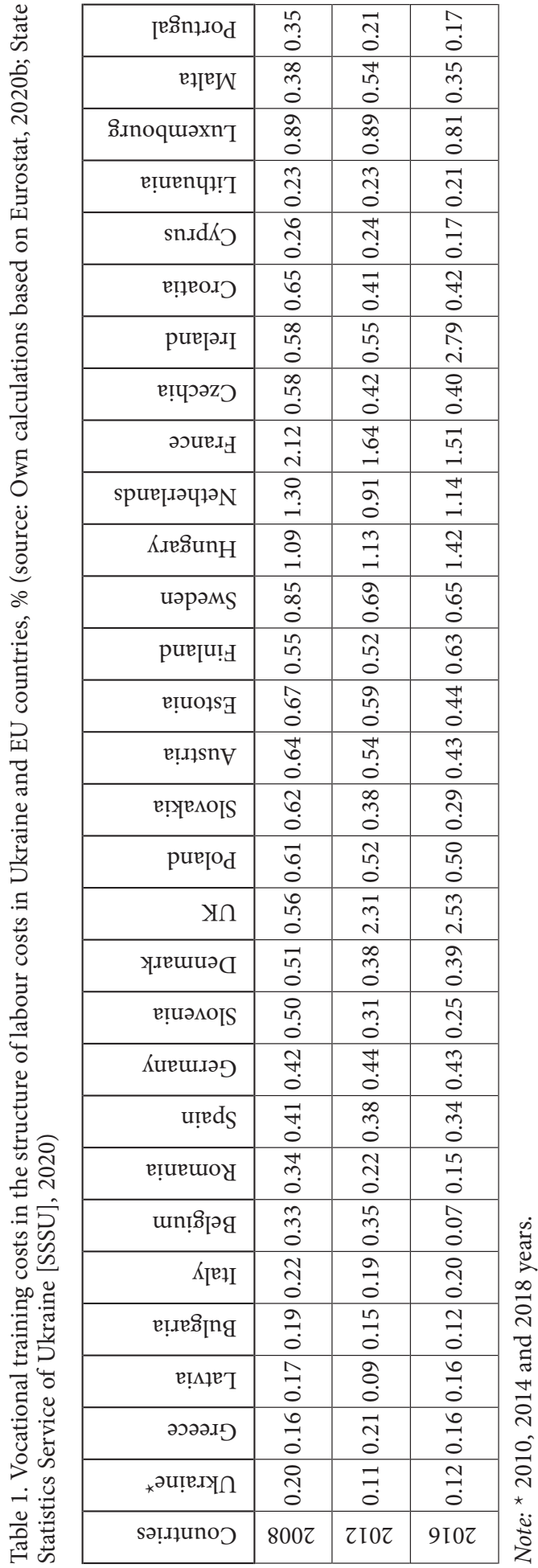


in European countries in 2016: in the EU countries, the average costs of training of one employee was five times higher, in Ireland and the UK - 20 times, in France and Hungary -10 times, and in Poland - 4 times.

In addition, although the share of vocational training costs in total staff costs in Ukraine is higher than in Belgium, they are significantly lower in monetary terms. For example, in 2016, the average costs per employee per hour in Belgium comprised 38.6 euros, 0.078 euros $(0.07 \%)$ of which went to vocational training; and in Ukraine, in 2018, similar costs were only 0.002 euros (this was $0.12 \%$ out of 2.3 euros). At the same time, the growth rate of vocational training costs in Ukraine has an unstable trend and lags significantly behind the growth rate of overall labour costs (Table 2).

Table 2. Dynamics of labour costs and vocational training costs in Ukraine (source: Own calculations based on SSSU, 2020)

\begin{tabular}{|l|c|c|c|c|c|c|c|}
\hline \multirow{2}{*}{ Indicators } & \multicolumn{2}{|c|}{2010} & \multicolumn{2}{c|}{2014} & \multicolumn{2}{c|}{2018} & \begin{tabular}{c} 
Growth \\
rate, \\
\cline { 2 - 8 }
\end{tabular} \\
\cline { 2 - 8 } & $€$ & $\%$ & $€$ & $\%$ & $€$ & $\%$ & $1.0018 / 2010$ \\
\hline The total cost per employee & 355.1 & 100 & 275.4 & 100 & 355.3 & 100 & 1.001 \\
\hline Incl. vocational training costs & 0.71 & 0.20 & 0.31 & 0.11 & 0.44 & 0.12 & 0.600 \\
\hline
\end{tabular}

Thus, a comparison of the costs of professional training of one employee in the EU and Ukraine, as well as a study of their dynamics, allow us to draw preliminary conclusions that investment in staff development is not perceived by Ukrainian business as a factor in forming their own competitiveness. At the same time, insufficient attention to this tool of increasing competitiveness can be traced even at large enterprises of Ukraine. In particular, in recent years, in large enterprises with 1,000 or more employees, the share of vocational training costs per employee has decreased from $0.19 \%$ to $0.15 \%$, in enterprises with $250-999$ employees - has almost halved. At the same time, in small and medium-sized enterprises (10-249 employees) the share of expenditures on employee training has not changed significantly and remains consistently low - within $0.1 \%$ (Figure 1 ).

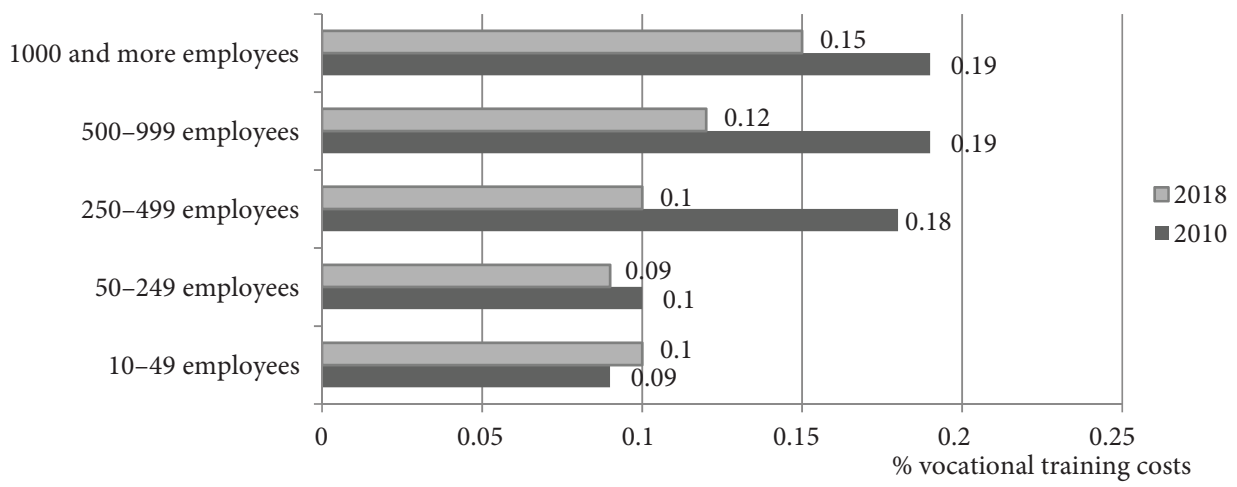

Figure 1. Share of vocational training costs per employee in enterprises with different numbers of employees (source: Own calculations based on SSSU, 2020) 
Given European integration intentions of Ukraine, it would be expedient for domestic businesses to use the tools of increasing competitiveness prevailing in the EU, in particular by increasing investments in human capital of their employees. Unfortunately, in this area of business management, the best practices of HR-management are not yet perceived by business owners in Ukraine as a factor of economic success, which is one of the significant internal threats to managing the competitiveness of the enterprise.

Therefore, the next step is an empirical study of the feasibility of increasing the business vocational training costs of employees, or at least their share in total labour costs, taking into account the possible economic benefits. To do this, the results of the authors' survey of employees at enterprises are used in one of the regional centres of Ukraine, conducted in 2018.

First of all, an attempt to identify the relationship between vocational training costs of employees and economic performance of enterprises, namely their profitability, is needed. Therefore, to check $H 1$, the answers of the respondents are grouped according to their affiliation to a profitable or non-profit enterprise. In addition, to assess the effectiveness of the collective agreement as an additional tool to stimulate the use of various training programs in enterprises, enterprises are divided by the criterion of existence/absence of a collective agreement.

As a result of the analysis of the questionnaires, the "coverage of short-term training programs" is found to be important for $67 \%$ of surveyed employees of profitable enterprises, and "coverage of long-term training" - for $39.2 \%$. At the same time, for employees of unprofitable enterprises, the employer's investment in their training is less important: $34.4 \%$ of respondents were interested in covering short-term training program costs, and only $9.4 \%$ were interested in covering long-term training program costs (Figure 2). However, the desire of employees to study at the expense of the enterprise is not fully satisfied and is mainly expressed in profitable enterprises. In particular, $40.1 \%$ of employees of profitable enterprises can count on the coverage of their short-term training costs, and $13 \%$ - on the coverage of

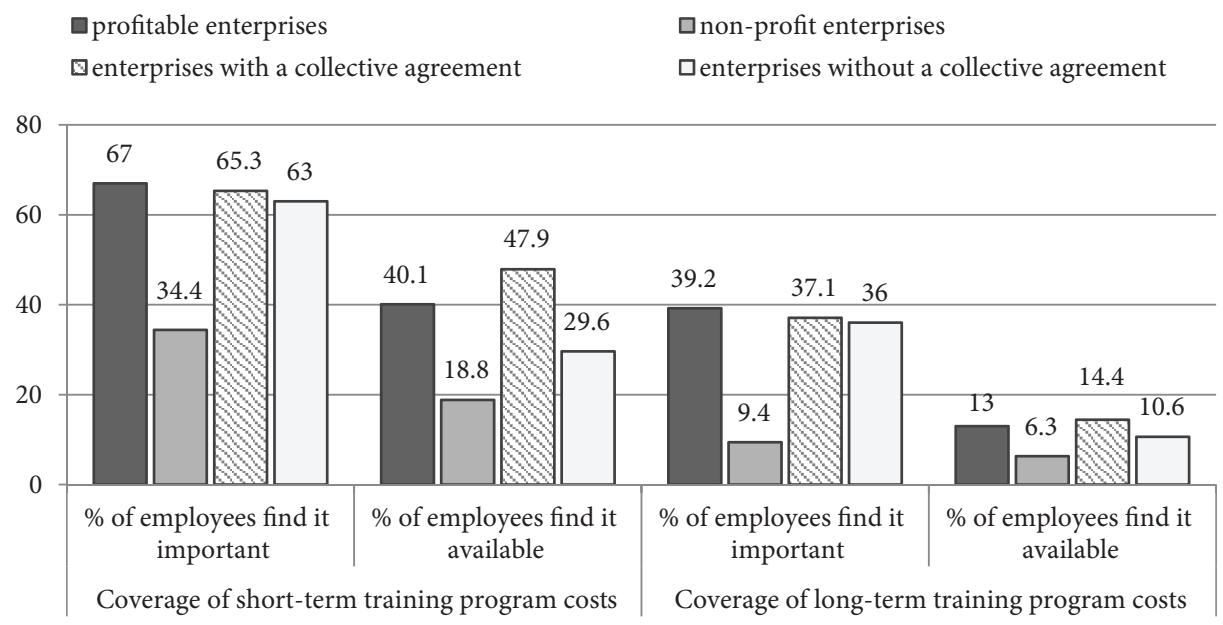

Figure 2. The importance and availability of training programs for employees of enterprises with different indicators of profitability and the existence of collective agreements 
long-term training program costs. At the same time, only for $25.1 \%$ of employees of unprofitable enterprises, there is training available at the expense of the enterprise under long-term and short-term programs.

The existence of a collective agreement at the enterprise, in which the employer's financing of employee training can be fixed, has a positive effect on the share of employees for whom training becomes available. However, the employer's main commitment is to pay for short-term training programs (courses, trainings, workshops, etc.), which becomes available to $47.9 \%$ of employees (Figure 2). At the same time, only $14.4 \%$ of employees can count on long-term training (higher education, internship abroad), which is expensive, even if the company has a collective agreement.

Thus, under the conditions of weak development of social dialogue, which is a characteristic feature of Ukrainian enterprises (Bilan et al., 2020b), the existence of a collective agreement, which enshrines certain benefits for employees, has a positive impact on vocational training programs. In turn, the underestimation of the importance of VTC in the structure of personnel costs by business owners reduces their economic results. Thus, regardless of the availability of profits, each company has employees (albeit different numbers and shares) for whom training is available. But more active financing of such programs is a sign of profitable enterprises. It should be borne in mind that such personnel costs are not a determining component of the enterprises' gross costs, which can significantly reduce their profits. Therefore, the interdependence of these indicators is as follows: the profitability of activities depends on the efforts of entrepreneurs to train their employees, and not vice versa. These findings are in line with conclusions on positive links between professional education and opportunities in business (Grabara et al., 2020). The appropriate direction of entrepreneurship development demands relevant efforts to create thriving environment for business support (Sułkowski \& Patora-Wysocka, 2020).

The economic results achieved by enterprises in the form of profits at the macroeconomic level are part of the overall economic success of the country in the form of GDP. It covers all the individual results of the enterprises of a particular country, including profits. That is, if the size of vocational training costs of staff affects the size of corporate profits, it should also affect the size of GDP.

Therefore, in order to check $H 2$, the relationship between vocational training costs and GDP per capita of EU countries was analyse by using formula 2. The factor indicator is vocational training costs per employee $(x)$, and the effective one is GDP per capita $(y)$. The value of indicator $(x)$ was calculated by multiplying the share of vocational training costs by total labour costs per employee in full-time equivalents per year. The calculations are given in Table 3.

Therefore, using the Fechner correlation coefficient (formula 2), the strength of the correlation between $(x)$ and $(y)$ was found:

$$
\rho F(x, y)=\frac{C-H}{C+H}=\frac{24-4}{24+4}=0.714 \text {. }
$$

Since the Fechner coefficient is 0.714 , there is a direct and fairly close relationship between the studied features. That is, the growth of investment in lifelong learning at the enter- 
prise level gives an increase in GDP per capita. In addition, the results presented in Table 3 show an almost uniform orientation of personnel development policy at the business level in different EU countries.

Table 3. Correlation between vocational training costs and GDP per capita (source: Own calculations based on Eurostat, 2020a, 2020b)

\begin{tabular}{|c|c|c|c|c|c|}
\hline Countries & $x_{i}$ & $y_{i}$ & $\operatorname{sgn}\left(x_{i}-\bar{x}\right)$ & $\operatorname{sgn}\left(y_{i}-\bar{y}\right)$ & $\mathrm{C} / \mathrm{H}$ \\
\hline Austria & 249 & 36500 & - & + & $\mathrm{H}$ \\
\hline Belgium & 40 & 33800 & - & + & $\mathrm{H}$ \\
\hline Bulgaria & 0.01 & 13900 & - & - & $\mathrm{C}$ \\
\hline Croatia & 71 & 17300 & - & - & $\mathrm{C}$ \\
\hline Cyprus & 48 & 24700 & - & - & $\mathrm{C}$ \\
\hline Czechia & 73 & 24900 & - & - & $\mathrm{C}$ \\
\hline Denmark & 258 & 36100 & - & + & $\mathrm{H}$ \\
\hline Estonia & 84 & 21700 & - & - & $\mathrm{C}$ \\
\hline Finland & 346 & 31200 & + & + & $\mathrm{C}$ \\
\hline France & 822 & 29800 & + & + & $\mathrm{C}$ \\
\hline Germany & 244 & 35100 & - & + & $\mathrm{H}$ \\
\hline Greece & 43 & 19300 & - & - & $\mathrm{C}$ \\
\hline Hungary & 203 & 19200 & - & - & $\mathrm{C}$ \\
\hline Ireland & 1444 & 50000 & + & + & $\mathrm{C}$ \\
\hline Italy & 90 & 27700 & - & - & $\mathrm{C}$ \\
\hline Latvia & 21 & 18300 & - & - & $\mathrm{C}$ \\
\hline Lithuania & 27 & 21500 & - & - & $\mathrm{C}$ \\
\hline Luxembourg & 535 & 76600 & + & + & $\mathrm{C}$ \\
\hline Malta & 91 & 27100 & - & - & $\mathrm{C}$ \\
\hline Netherlands & 680 & 36300 & + & + & $\mathrm{C}$ \\
\hline Poland & 73 & 19400 & - & - & $\mathrm{C}$ \\
\hline Portugal & 40 & 21900 & - & - & $\mathrm{C}$ \\
\hline Romania & 15 & 16900 & - & - & $\mathrm{C}$ \\
\hline Slovakia & 50 & 20600 & - & - & $\mathrm{C}$ \\
\hline Slovenia & 69 & 23500 & - & - & $\mathrm{C}$ \\
\hline Spain & 124 & 25900 & - & - & $\mathrm{C}$ \\
\hline Sweden & 415 & 35000 & + & + & $\mathrm{C}$ \\
\hline UK & 1295 & 30700 & + & + & $\mathrm{C}$ \\
\hline Average value & 266 & 28389 & & & \\
\hline
\end{tabular}




\section{Conclusions}

With the spread of vocational training practices at enterprises, their positive impact on economic benefits is quite theoretically and empirically proven not only for individuals and firms, but also for the country as a whole. After all, the result of such training contributes to the competitiveness of both the employee and the company, and thus has a positive relationship with income, profits and, consequently, the country's GDP. Unfortunately, Ukraine is one of the countries with incomparably low (compared to the practice of HRM in the EU) costs for vocational training of the adult working population.

After testing hypothesis 1 about the relationship between the cost of vocational education at the enterprise level and the profitability of their activities, it was found that about $50 \%$ of employees of profitable enterprises can count on covering their costs for various training programs, and only $25 \%$ of the employees at non-profit enterprises have this opportunity. In addition, it was found that the costs of vocational training are more actively covered at enterprises where the relationship between the administration and employees is further regulated by a collective agreement. Such arrangements encourage/oblige companies to invest in life-long education of staff, which at the same time has a positive effect on employees' loyalty to the company.

To establish the link between investment in human capital and economic success, the Fechner correlation coefficient was used, which allows taking into account the existing average standards in the policy of personnel development at the level of business in different countries of the same group. The test results of the hypothesis 2 confirmed a close and positive relationship between vocational training costs and GDP per capita. This revealed a common approach to building and supporting a system of their own staff development by European enterprises within most EU countries.

Thus, the issue of investment in staff development should attract the attention of Ukrainian companies, as this tool can increase the competitiveness of the enterprise and its economic results. The fact, that monitoring VTCs and their impact on economic success at various levels require constant attention, has been sufficiently proven by other scientists. At the same time, the creation of a unified system of statistical observations in this direction does not seem possible or appropriate due to significant differences in the strategic objectives of enterprises, as well as clear restrictions on the disclosure of information that may create competitive advantages. Such restrictions are considered to be objectively existing and justified. At the same time, numerous empirical studies, which prove the positive impact of VTC on the economic results of business, are an important argument in favour of borrowing not only the European experience of organizing relevant training programs, but also encouraging employers to use them more actively.

Such incentives in the form of known tax benefits, as well as the regulation of the tax base in the case of reasonable use of VTC are also well known. In this case, the issue is not only the social responsibility of the business or its pragmatism in understanding its benefits from funding training programs. The improvement of state policy requires greater development and further argumentation, including scientific one, in order to encourage business owners to life-long staff training. At least, this is important if the country is interested in economic 
progress based on the development of knowledge in the system of vocational training at enterprises. The study of such opportunities and their scientific justification are among the prospects for further research in this area.

\section{Acknowledgements}

This research was supported by the Ministry of education, science, research and sport of the Slovak Republic [grant VEGA 1/0689/20 Digital economy and changes in the education system to reflect labour market demands].

\section{Author contributions}

NS conceived the study and was responsible for the design and development of the data analysis. HM was responsible for the literature review while NS and YB were responsible for data collection and analysis. YB and HM were responsible for data interpretation.

\section{Disclosure statement}

The authors declare that they have no conflict of interest.

\section{References}

Al Karim, R. (2019). Impact of different training and development programs on employee performance in Bangladesh perspective. International Journal of Entrepreneurial Research, 2(1), 8-14. https://doi.org/10.31580/ijer.v2i1.497

Al Mamun, C. A., \& Hasan, M. N. (2017). Factors affecting employee turnover and sound retention strategies in business organization: a conceptual view. Problems and Perspectives in Management, 15(1), 63-71. https://doi.org/10.21511/ppm.15(1).2017.06

Al-Ajlouni, M. I., Nawafleh, S., \& Alsari, H. (2019). The moderating effect of electronic-HRM on training and employee performance relationship: a moderated model. International Journal of Management Practice, 12(4), 511-532. https://doi.org/10.1504/IJMP.2019.102572

Australian Government. (2020). Productivity commission, national agreement for skills and work force development review (Interim report).

https://www.pc.gov.au/inquiries/current/skills-workforce-agreement/interim

Avis, J. (2018). Socio-technical imaginary of the fourth industrial revolution and its implications for vocational education and training: a literature review. Journal of Vocational Education \& Training, 70(3), 337-363. https://doi.org/10.1080/13636820.2018.1498907

Bhorat, H., Cassim, A., \& Tseng, D. (2016). Higher education, employment and economic growth: Exploring the interactions. Development Southern Africa, 33(3), 312-327. https://doi.org/10.1080/0376835X.2016.1161501

Bibi, M. (2018). Impact of talent management practices on employee performance: An empirical study among healthcare employees. SEISENSE Journal of Management, 2(1), 22-32. https://doi.org/10.33215/sjom.v2i1.83 
Bilan, Y., Mishchuk, H., Roshchyk, I., \& Joshi, O. (2020a). Hiring and retaining skilled employees in SMEs: problems in human resource practices and links with organizational success. Business: Theory and Practice, 21(2), 780-791. https://doi.org/10.3846/btp.2020.12750

Bilan, Y., Mishchuk, H., Samoliuk, N., \& Mishchuk, V. (2020b). Gender discrimination and its links with compensations and benefits practices in enterprises. Entrepreneurial Business and Economics Review, 8(3), 189-204. https://doi.org/10.15678/EBER.2020.080311

Boadu, F., Xie, Y., Du, Y. F., \& Dwomo-Fokuo, E. (2018). MNEs subsidiary training and development and firm innovative performance: The moderating effects of tacit and explicit knowledge received from headquarters. Sustainability, 10(11), 4208. https://doi.org/10.3390/su10114208

Choi, S. J., Jeong, J. C., \& Kim, S. N. (2019). Impact of vocational education and training on adult skills and employment: An applied multilevel analysis. International Journal of Educational Development, 66, 129-138. https://doi.org/10.1016/j.ijedudev.2018.09.007

Chung, T. A., \& Tseng, C. Y. (2019). The knowledge intensity and the economic performance in Taiwan's knowledge intensity business services. Economic Research-Ekonomska Istraživanja, 32(1), 797-811. https://doi.org/10.1080/1331677X.2019.1583586

Cochran, W. G. (1977). Sampling techniques (3rd ed.). John Wiley \& Sons.

Della Torre, E. (2019). Collective voice mechanisms, HRM practices and organizational performance in Italian manufacturing firms. European Management Journal, 37(3), 398-410.

https://doi.org/10.1016/j.emj.2018.09.001

Dincă, V. M., Dima, A. M., \& Rozsa, Z. (2019). Determinants of cloud computing adoption by Romanian SMEs in the digital economy. Journal of Business Economics and Management, 20(4), 798-820. https://doi.org/10.3846/jbem.2019.9856

Efobi, U., \& Orkoh, E. (2018). Analysis of the impacts of entrepreneurship training on growth performance of firms: Quasi-experimental evidence from Nigeria. Journal of Entrepreneurship in Emerging Economies, 10(3), 524-542. https://doi.org/10.1108/JEEE-02-2018-0024

Eurostat. (2020a). Database on Gross domestic product (GDP). https://ec.europa.eu/eurostat/tgm/table. $\mathrm{do} ? \mathrm{tab}=$ table\&init $=1 \&$ language $=$ en $\&$ pcode $=$ sdg_10_10\&plugin $=1$

Eurostat. (2020b). Database on Labour cost surveys 2008, 2012 and 2016. https://ec.europa.eu/eurostat/data/database

Falola, H. O., Salau, O. P., Olokundun, M. A., Oyafunke-Omoniy, C. O., Ibidunni, A. S., \& Oludayo, O. A. (2018). Employees' intrapreneurial engagement initiatives and its influence on organisational survival. Business: Theory and Practice, 19, 9-16. https://doi.org/10.3846/btp.2018.02

Görlitz, K., \& Tamm, M. (2016). The returns to voucher-financed training on wages, employment and job tasks. Economics of Education Review, 52, 51-62. https://doi.org/10.1016/j.econedurev.2016.01.004

Grabara, J., Hussain, H. I., \& Szajt, M. (2020). Sustainable university development through sustainable human resources and corporate entrepreneurship: The role of sustainable innovation and work environment. Amfiteatru Economic, 22(54), 480-495. https://doi.org/10.24818/EA/2020/54/480

Grenčíková, A., Kordoš, M., \& Navickas, V. (2021). The impact of Industry 4.0 on education contents. Business: Theory and Practice, 22(1), 29-38. https://doi.org/10.3846/btp.2021.13166

Guan, X., \& Frenkel, S. (2019). How perceptions of training impact employee performance. Personnel Review, 48(1), 163-183. https://doi.org/10.1108/PR-05-2017-0141

Islam, R., Ghani, A. B. A., Kusuma, B., \& Theseira, B. B. (2016). Education and human capital effect on Malaysian economic. International Journal of Economics and Financial Issues, 6(4), 1722-1728. https://search.proquest.com/docview/1836597485?pq-origsite=gscholar\&fromopenview=true

Krumbiegel, K., Maertens, M., \& Wollni, M. (2018). The role of Fairtrade certification for wages and job satisfaction of plantation workers. World Development, 102, 195-212.

https://doi.org/10.1016/j.worlddev.2017.09.020 
Kruskal, W. H. (1958). Ordinal measures of association. Journal of the American Statistical Association, 53(284), 814-861. https://doi.org/10.2307/2281954

Kumar, R., Mandava, S., \& Gopanapalli, V. S. (2019). Vocational training in India: Determinants of participation and effect on wages. Empirical Research in Vocational Education and Training, 11(3), 1-17. https://doi.org/10.1186/s40461-019-0078-y

Martins, P. S. (2020). Employee Training and Firm Performance: Quasi-experimental evidence from the European Social Fund (GLO Discussion Paper Series, No. 488). http://cver.lse.ac.uk/publications/abstract.asp?index $=6941$

Mason, G. (2020). Higher education, initial vocational education and training and continuing education and training: Where should the balance lie? Journal of Education and Work, 33(7-8), 468-490. https://doi.org/10.1080/13639080.2020.1755428

McGrath, S., \& Powell, L. (2016). Skills for sustainable development: Transforming vocational education and training beyond 2015. International Journal of Educational Development, 50, 12-19. https://doi.org/10.1016/j.ijedudev.2016.05.006

Mira, M., \& Odeh, K. (2019). The mediating role of authentic leadership between the relationship of employee training and employee performance. Management Science Letters, 9(3), 381-388. https://doi.org/10.5267/j.msl.2018.12.011

Mishchuk, H., Bilan, Y., \& Pavlushenko, L. (2016). Knowledge management systems: Issues in enterprise human capital management implementation in transition economy. Polish Journal of Management Studies, 14(1), 163-173. https://doi.org/10.17512/pjms.2016.14.1.15

Mishchuk, H., Roshchyk, I., Sułkowska, J., \& Vojtovič, S. (2019). Prospects of assessing the impact of external student migration on restoring the country's intellectual potential (Case Study of Ukraine). Economics and Sociology, 12(3), 209-219. https://doi.org/10.14254/2071-789X.2019/12-3/14

Muehlemann, S. (2019). Measuring performance in vocational education and training and the employer's decision to invest in workplace training. In The Wiley handbook of vocational education and training (pp. 187-206). John Wiley \& Sons. https://doi.org/10.1002/9781119098713.ch10

National Centre for Vocational Education Research. (2020). Australian vocational education and training statistics: Apprentice and trainee experience and destinations - time series 2008, 2010 and 2019. https://www.voced.edu.au/content/ngv:86981

Ogundari, K., \& Awokuse, T. (2018). Human capital contribution to economic growth in Sub-Saharan Africa: Does health status matter more than education? Economic Analysis and Policy, 58, 131-140. https://doi.org/10.1016/j.eap.2018.02.001

Reed, D., Cook, K., \& Aloe, A. (2018). A cost-benefit analysis of summer reading programs implemented under state guidelines. Educational Policy, 34(4), 594-618. https://doi.org/10.1177/0895904818802112

Saksiriruthai, S. (2018). Impact of media technology on wage changes: The case of Thailand. Journal of International Studies, 11(4), 69-78. https://doi.org/10.14254/2071-8330.2018/11-4/5

Shah, C. (2017). Employers' perspectives on training: Three industries (NCVER Research Report). National Centre for Vocational Education Research (NCVER). https://eric.ed.gov/?id=ED577694

Starr, E. (2019). Consider this: Training, wages, and the enforceability of covenants not to compete. ILR Review, 72(4), 783-817. https://doi.org/10.1177/0019793919826060

State Statistics Service of Ukraine. (2020). Labour cost-surveys 2010, 2014 and 2018. http://ukrstat.gov.ua/

Suharno, S., Pambudi, N. A., Widiastuti, I., \& Harjanto, B. (2019). Apprenticeship implementation of productive teacher at Vocational School in Indonesia. In 5th UPI International Conference on Technical and Vocational Education and Training (ICTVET 2018) (pp. 88-95). Atlantis Press. https://doi.org/10.2991/ictvet-18.2019.20 
Sułkowski, Ł., \& Patora-Wysocka, Z. (2020). International entrepreneurship of universities: Processoriented and capabilities perspectives. Entrepreneurial Business and Economics Review (EBER), 8(3), 175-188. https://doi.org/10.15678/EBER.2020.080310

Tvaronavičiene, M., Tarkhanova, E., \& Durglishvili, N. (2018). Sustainable economic growth and innovative development of educational systems. Journal of International Studies, 11(1), 248-256. https://doi.org/10.14254/2071-8330.2018/11-1/19

United Nations Development Programme. (2019). Human development report 2019. Beyond income, beyond averages, beyond today: Inequalities in human development in the 21st century. New York. https://doi.org/10.18356/838f78fd-en

Varma, N. S., \& Kataria, N. (2018). Sustainable growth through vocational education: Analysis of its impact on Indian economy. International Research Journal of Marketing and Economics, 5(8), 58-70.

Wang, C., Zhang, B., Oláh, J., \& Hasan, M. (2021). Factors influencing the quality of life of empty nesters: Empirical evidence from Southwest China. Sustainability, 13(5), 2662. https://doi.org/10.3390/su13052662

Yusoff, M. N. H., Al Mamun, A., Ibrahim, M. D., \& Hassan, H. (2018). Measuring and comparing functional business skills and knowledge among Asnaf community in Malaysia. Economics and Sociology, 11(2), 229-247. https://doi.org/10.14254/2071-789X.2018/11-2/16 